Article

\title{
Factors in the Relationship between Maintenance Engineering and Knowledge Management
}

\author{
Javier Cárcel-Carrasco ${ }^{1, * \mathbb{D}}$, José-Antonio Cárcel-Carrasco ${ }^{1,2}$ (D) and Elisa Peñalvo-López ${ }^{1}$ (D) \\ 1 Universitat Politècnica de València, Camino de Vera s/n, 46022 València, Spain; \\ jacarcel@tecnatom.es (J.-A.C.-C.); elpealpe@upvnet.upv.es (E.P.-L.) \\ 2 Tecnatom S.A., C.N Cofrentes s/n, 46625 Cofrentes, València, Spain \\ * Correspondence: fracarc1@csa.upv.es; Tel.: +34-9638-77000
}

Received: 14 March 2020; Accepted: 16 April 2020; Published: 18 April 2020

\begin{abstract}
The mechanisms of transmission and management of knowledge are mostly created by maintenance and exploitation activities of large buildings and industrial facilities, but they are poorly studied due to the difficulty capturing themas they belong to tacit knowledge gained by the experience of the maintenance staff. These professionals are highly qualified and are accostumed to solving technical problems even under pressure. The loss of these professionals means losing also an important asset of the company. This article will tackle the importance of the factors that influence knowledge management $(\mathrm{KM})$ in maintenance engineering and its barriers and facilitators. The research is carried out by qualitative investigation on maintenance staff of an industrial company.
\end{abstract}

Keywords: knowledge management (KM); industrial maintenance; exploitation and conduction of the facilities; tacit knowledge; industry 4.0

\section{Introduction}

The term industry 4.0 promotes knowledge management in all departments of an industry. But within the maintenance departments of companies, this is difficult due to the way in which their technicians are used to working based on their experience and not upon sharing and explaining their knowledge of operating.

The reliability, availability, maintainability, security and operational costs are the base for maintenance performance. It is noteworthy the human factor role in the operability $[1,2]$ due to the tacit knowledge generated by the maintenance activities and staff.

Industry 4.0 will generate new services and products, increasing productivity and new qualified jobs in the industry. Faced with this transformation, people from all departments of an industry must have new skills and competencies to work in Industry 4.0. This will require a qualification and knowledge management for companies [3,4]. Maintenance departments within companies operate with technicians with high knowledge based on their professional experiences, with a high component of tacit knowledge and, traditionally, with null knowledge management policies [2].

Knowledge is the capacity to act, process and interpret the information for generate more knowledge or solve specific problem [5]. Nowadays, knowledge and ideas are the components for the growth and change of companies and sectors where the use of traditional resources is limited. The strategic management of the companies is based on knowledge, where the intangible assests are more valued compared to the active assets of the companies [3,6]. Therefore, knowledge is considered an important intangible component in companies [7].

A deepening in measures of maintenance services will lead to energy efficiency and a production improvement [8,9]. As is well known knowledge about facilities is important in maintenance services as it the key to transform tacit knowledge into explicit knowledge. 
To create an intangible value in knowledge and solve new actions, a change in the knowledge-based model and learning are required which will make the organization more efficient by focusing on learning and innovating. The knowledge is a strategic factor and a useful solution tool [10,11].

To deepen the study in tactic actions of industrial trades creates an efficient improvement and a reduction in a company's costs as unwanted actions will not occur such as production interruption, energy loss, efficiency loss or systems and facilities reliability.

Experienced staff is a key component in the company as the reliability of the systems are directly related to them $[12,13]$ and with their personal knowledge the improvement in knowledge organization can be achieved [14,15].

To transfer knowledge into newly incorporated staff the subcontracting of industrial services is efficient as this reduces external rotations, and this methodology is a medium-term activity due to the lack of time to transfer information $[16,17]$.

The operational impact of the maintenance actions affects the company and its tactical actionsdirectly, so condition verifications are necessary in order to obtain knowledge [18]. Knowledge managements implies the use of practices with difficulty in observation and manipulation or are unknown to those who possess them. In Figure 1, it can be seen the different factors that affect maintenance:

THE KNOWLEDGE FACTORS AND THE MAINTENANCE EXPERIENCE

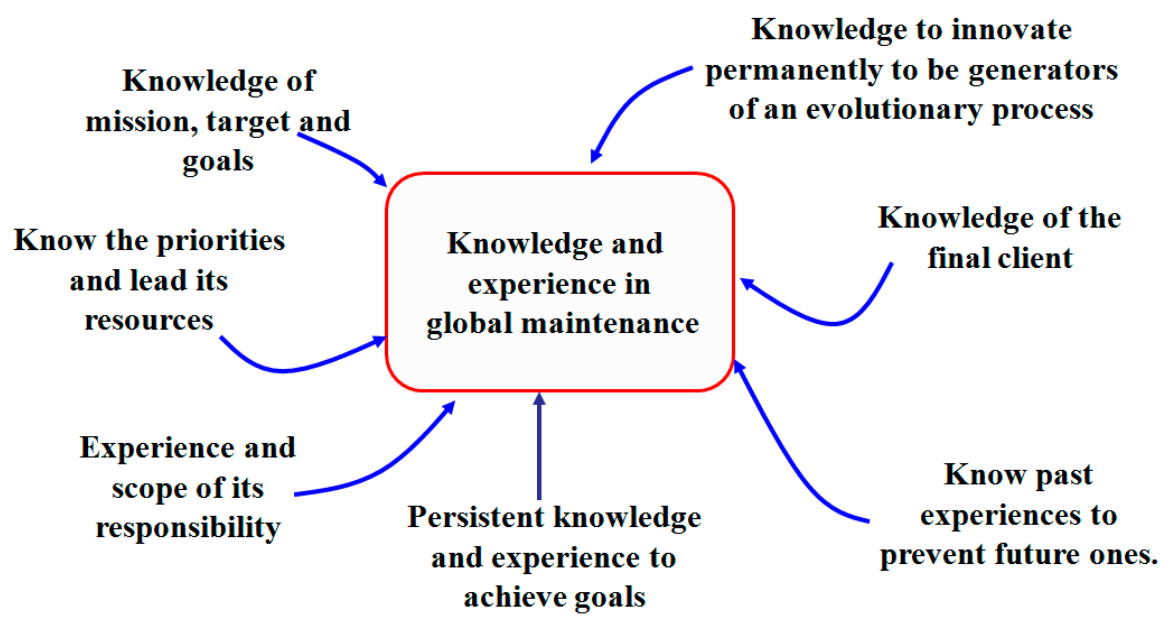

Figure 1. Knowledge factors related to maintenance.

There are two types of knowledge: tacit and explicit knowledge, and both present a denpendency on each other [19]. Tacit knowledge is the one gained with experience [20] in contrast with explicit knowledge which can be transferred by formal and systematic sources, such as, computer software or diagrams.

In maintenance engineering, there is a transformation of tacit knowledge (individual level) into explicit knowledge (group and organizational level) [21]. Once the knowledge is explicit, it turns into tacit knowledge by the action of internalisation by the members. This process generates four phases: Socialization, outsourcing, combination and internalisation. Because of these phases, the knowledge can be formed, created and transmitted [22] (Figure 2). 
THE KNOWLEDGE IN INDUSTRIAL MAINTENANCE ACCORDING TO THE NONAKA MODEL.

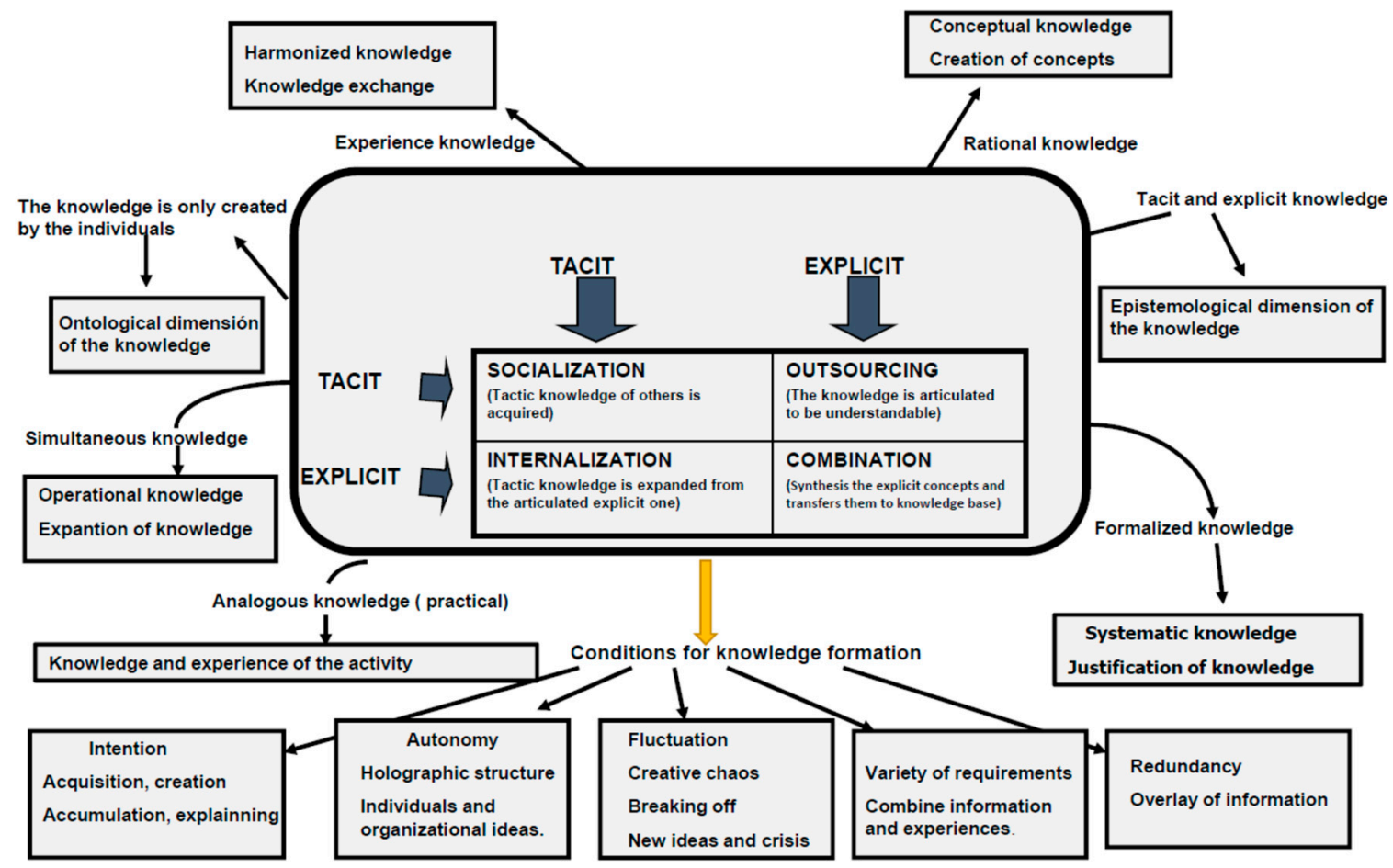

Figure 2. Industrial knowledge according to the Nonaka model.

There are many studies on knowledge management in different industrial and service activities, and the effect on their application, but usually such studies focus on global management (especially the most explicit part of the work), influencing trade, internal or accounting administrative management, R\&D or development activities, information technology companies (IT), etc. [23-27], but sparsely on the tactical actions of industrial trades such as maintenance engineering. The maintenance activity, as it is organized and due to its own specificity, fundamentally generates tacit knowledge based on experience, at levels much higher than are explicit, which is also recorded in a fragmented way. In general, there are mature workers, with a lot of experience due to the great specialization required and, in addition, a type of information is created that is not elaborate and weakly oriented to decision-making [2]. That is why managing knowledge in these areas of work implies, in itself, not only an improvement in the efficiency of the processes of the industrial internal trades, but also a reduction in expenses induced by the company itself (production stops, loss of energy efficiency, loss of reliability of systems and facilities and longer learning time for new technicians).

Large companies are ready to implement an increasingly sophisticated solution to improve their productivity. The near future may be represented by the so-called chatbot, already present on instant messaging platforms and destined to become increasingly popular [28]. But this is difficult to implement in maintenance engineering due to the large component of tacit knowledge with which it works.

\section{Materials and Methods}

The instruments used in the investigation are semi-structured interviews and analysis based on the grounded theory, direct observation and documents of the company related to the activity. Collecting information from different sources not only allows a better evaluation of the validation and generalization of the results, but also reduces the risk of having limited conclusion based on limited methods [29]. 
This investigation has studied 61 cases of industrial maintenance staff involved in the agro-food sector in Spain. The case study has been chosen because of its strategy to understand in depth the individual scenarios and its dynamics in order to discover new relationships and concepts, rather than verify previously established propositions [30-32].

For this study, different components were used, such as technicians and maintenance department managers related to the agri-food sector. The sample for this activity was formed by 10 maintenance managers and 51 maintenance technicians (Table 1). In the selected company, it has been assumed that the internal maintenance and operation departments aim to have high impact, in order to havenationwide implementation with industrial factories distributed in different territorial points. In the selection, the minimum experience is 10 years, so that they know the performance of their functions as well as the normal limitations in their job.

Table 1. Sample of qualitative study.

\begin{tabular}{|c|c|c|c|c|c|}
\hline \multicolumn{6}{|c|}{ Research Sample } \\
\hline Total company staff & \multicolumn{5}{|c|}{1137} \\
\hline Company sector & \multicolumn{5}{|c|}{ Agri-Food Industry Sector } \\
\hline \multirow[t]{3}{*}{ Maintenance area total staff. } & \multicolumn{5}{|c|}{230} \\
\hline & & \multicolumn{4}{|c|}{ Maintenance sections } \\
\hline & & Facilities & Production & Mechanical & Systems \\
\hline \multirow{2}{*}{ Interviewed maintenance staff } & Managers & 3 & 3 & 2 & 2 \\
\hline & $\begin{array}{l}\text { Operative } \\
\text { technicians }\end{array}$ & 12 & 14 & 16 & 9 \\
\hline Total interviewed cases & & & 61 & & \\
\hline
\end{tabular}

The script for the interview:

It is intended to study the factors involved in knowledge management in maintenance engineering within the industrial company. Based on your personal experience, answer the following questions:

1. Is there any knowledge management policy within the company? And within the maintenance activities?

2. In daily activities related to your duty, how do you create the knowledge that is normally used in your duty?

3. How is the coding and storage of the generated knowledge produced? How do you contribute to it? and the rest of coworkers?

4. How does the personal knowledge is transmitted? To what extent does the level of tacit knowledge affect the resolution of failures or unscheduled stops in these technical structures?

5. How do you use stored knowledge and how does it impact the company?

6. What barriers exist within the maintenance activities so the proper knowledge management can be achieved?

7. What would improve knowledge management in your work? What do you think you could do to improve it or the company?

8. What is the involvment of your senior regarding knowledge management?

9. Have any audits taken place? Have knowledge maps been created or used to clarify knowledge flows within the most important tactical activities?

The instruments used for this investigation are:

Grounded theory: this starts with a general sample of types of companies or people and it will be adjusted as the research progresses. 
In order to obtain information that does not influence the answers of the interviewees, a semi-structured protocol is followed with a flexible style. The interviewee is an informer who provides relevant aspects and suggests additional sources [31].

Direct observation: this is a close examination of the different aspects of a phenomenon in order to study its characteristics and behavior. This technique provides additional information on the subject of the study. For the purpose of this research, the direct observation proposed by Yin (1995) [31] was conducted without protocols and preventing the feeling bythe observed subjects that they are under study. This observation was developed during the investigation stage, in which there was direct entry by the company in all areas where it performs the maintenance function.

Documents: are used for corroborating and increase the evidence of the sources. The documents are also useful for inferring issues that are not previously evaluated [31]. The analysed documents were documents used in daily practice (work parts, maintenance programs), planimetry and photographic documents and processes available to the organization itself. The step prior to the data analysis was to transcribe the interviews, notes taken during interview, observations and useful information of the reviewed documents.

Having the information written of each case in a single document allowed us to analyze the information in a clearer way within a cluster of data and compare them from different evidences [30]. The cases studied were analyzed individually and cross-based having as a base the strategies of the categorization and contextualization described by Maxwell [29]. The data analysis was undertaken with Atlas.ti 5.0 an app by Research Talk Inc.

\section{Results}

The list of categories was started during the data collection stage, based on theory, research questions and interview summaries. This list was modified throughout the fieldwork and during the case analysis. The categorization of the data in each case was an iterative process in which the data was assigned to the following categories:

- Acquisition of external and internal knowledge: both internal and external activities support the organizational process and provides new maintenance knowledge.

- Important elements of knowledge generation: individual and organizational actions support or restrict the knowledge generation.

- Transfer of knowledge through informal or formal mechanisms: the formal mechanisms codify or store the knowledge through the data base, documents or computer tools which are easily accessible to any member [33]. While informal mechanisms transfer knowledge by direct contact.

- Important elements of knowledge transfer: individual and organizational actions support or limit the knowledge transfer.

- Use of knowledge: apply the knowledge in daily maintenance activities of the company.

- Use of tools for knowledge management: a clear improvement is reached by the proper use of audits and knowledge maps.

Following analysis of the cases, both individually and crossed, it was possible to detect the main factors involved in the management of knowledge in the maintenance activity, barriers and facilitators. The interaction of organizations with their environment, along with the means, are used to create and distribute the information and knowledge [34].

There are various factors that are directly related to the operational reliability and economic impacts hence they influence on the efficiency of the company (Table 2). 
Table 2. Knowledge management (KM) factors observed by their dimensions.

\begin{tabular}{|c|c|c|}
\hline $\begin{array}{l}\text { Studied Phenomenon } \\
\text { Category }\end{array}$ & Maintenance Operational Technicians & Maintenance Managers \\
\hline $\begin{array}{l}\text { Knowledge Production } \\
\text { and Acquisition }\end{array}$ & $\begin{array}{l}\text { External: } \\
\text { Material and equipment suppliers. } \\
\text { Catalogues and manufacturers guides. } \\
\text { External installation and assembly companies. } \\
\text { The internal customer itself (rest of the industry). } \\
\text { Internal: } \\
\text { Self-learning. } \\
\text { Training courses. } \\
\text { Formal meetings. } \\
\text { Informal meetings with other colleagues. }\end{array}$ & $\begin{array}{l}\text { External: } \\
\text { Contact with sector of the company (production } \\
\text { and maintenance areas). } \\
\text { Material and equipment suppliers. } \\
\text { Catalogues and manufacturers guides. } \\
\text { External installation and assembly companies. } \\
\text { Meetings with profesional associations. } \\
\text { The internal customer itself (rest of the industry). } \\
\text { Online inquiries. } \\
\text { Attendance to congresses and sectorial fairs. } \\
\text { Internal: } \\
\text { Self-learning. } \\
\text { Training courses. } \\
\text { Meetings in the area. }\end{array}$ \\
\hline Knowledge Transfer & $\begin{array}{l}\text { Formal mechanisms: } \\
\text { Documents. } \\
\text { Intranet. } \\
\text { Maintenance área meetings. } \\
\text { Informal meetings: } \\
\text { Face to face communication. } \\
\text { Hallway conversations. }\end{array}$ & $\begin{array}{l}\text { Formal mechanisms: } \\
\text { Documents. } \\
\text { Intranet. } \\
\text { Maintenance área meetings. } \\
\text { Analysis of quantitative data of indicators. } \\
\text { Informal mechanisms: } \\
\text { Face to face communication. } \\
\text { Hallway conversations. } \\
\text { Meetings with other companies' colleagues. } \\
\text { Emails. } \\
\text { Intranet. }\end{array}$ \\
\hline Use of Knowledge & $\begin{array}{l}\text { Breakdown repairs. } \\
\text { Work environment understanding. } \\
\text { Actions opportunity. }\end{array}$ & $\begin{array}{l}\text { Maintenance planning. } \\
\text { Establish priorities. } \\
\text { Optimize technical resources. } \\
\text { Economic optimization. } \\
\text { Response and reliability. } \\
\text { improvements. }\end{array}$ \\
\hline
\end{tabular}

\section{Discussion}

There are various factors that are directly related to the operational reliability and economic impacts hence they influence on the efficiency of the company (Table 2). The analysed data shows the existence of divergence between maintenance managers and technicians, as the first group is professionaly formed with higher education and they have more software knowledge along with a organizational component of their function.

Knowledge production and acquisition: the sources for external knowledge are the subcontracting companies, installer companies, material and equipment manufacturers and connections with other maintenance companies. Internal knowledge is acquired by meetings, informals conversations between workers and the self-learning. These internal or external activities are the support for organizational processes and provides new maintenance knowledge.

Other important elements to generate knowledge are the proactive attitude of the management team, motivation of involved staff and organizational culture in the maintenance department.

Employees being part of decision-making activities affects positively on production and acquisition of external knowledge. Regarding the internal knowledge, it is acquired from the internal clients as they give opportunity to the organization about different services and demands from them. Internal 
knowledge is also gained by self-learning techniques and maintenance staff meetings. Self-learning techniques depend on individual tacit knowledge developed by the experience, learning through social interaction and communication within the company which promotes a participatory management style [35]. Meetings are mainly used for organizational knowledge creation and promote the learning of the staff along with the creationof new ideas.

Knowledge transfer by formal and informal mechanisms: formal mechanisms codify and archive the knowledge in form of software or documents which are easily reachable by any member of the organization [33]. The informal mechanisms transfer the knowledge through direct contact such as meetings of the members since theywork as a knowledge transfer means. It must be emphasized that the documents have greater impact on the organization at the point of knowledge transfer, but the lack of time hinders the documentation of important actions.

The knowledge management team and technicians have different techniques to transfer knowledge. The first group transfer knowledge using emails or intranet, while the technicians have limited use of computer tools which makes them use their own knowledge. This indicates that technological tools used to transfer knowledge must be easy and simple, so it is reachable by any operational technician.

Use of knowledge and tools for its management: by applying the acquired knowledge on maintenance activities creates a positive effect and improvement in the company. Proper knowledge and information management affects positively on actions such as:

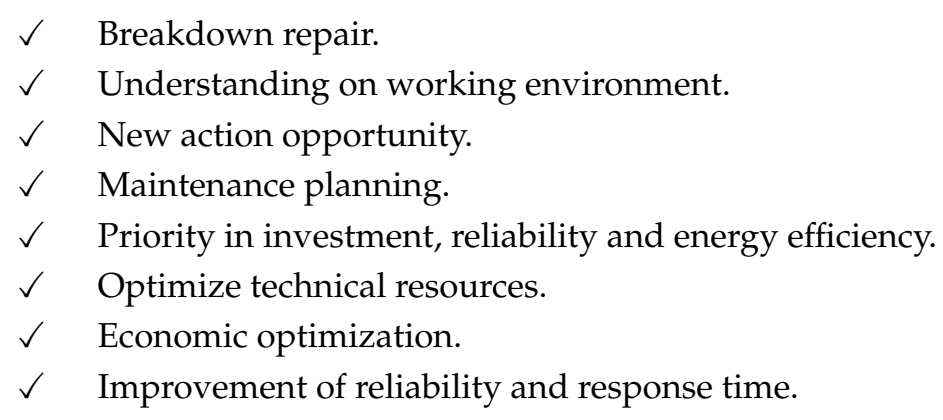

It is remarkable the use of diagrams only in certain facilities or equipment which limit the use of internal knowledge audits.

In Figure 3, the qualitative research on industrial maintenance is shown, where the learning system must be based on actions of acquisition, retention and use of knowledge. This structures the knowledge and how the learning is produced. The proposed system must be able to incorporate concepts and techniques of how the knowledge is applied, thus the efficiency in maintenance services is improved.

Barriers and facilitators of transfer and creation of knowledge in maintenance organizations: a flexible proactive organizational culture, together with a participatory style of management, are elements that allow activities to develop both in the generation and the transfer of knowledge within the organization. At the individual level, personal motivation and the opportunity to learn facilitates the generation of knowledge that when shared with other members of the company gives rise to organizational knowledge. The empirical evidence of this study shows that an open organizational culture motivates technicians to generate and share their knowledge in a more successful way and at the same time, and supports communication between company members. In maintenance controls, a grouped physical distribution of their jobs facilitates the transfer of knowledge

There is a need for a "knowledge manager" as this captures and tranfers the knowledge into various members. This figure must have technical training and clear concept of knowledge management with high experience so the knowledge can be easily shared into technicians and managers. This creates quality in maintenance services and therefore an improvement in the organization itself, along with a connection between the rest of the activities of the organization such as production, administration areas, etc. This suggests that the knowledge to be transfer must be a priority and has to be planned as rest of the strategic activities of the company. 


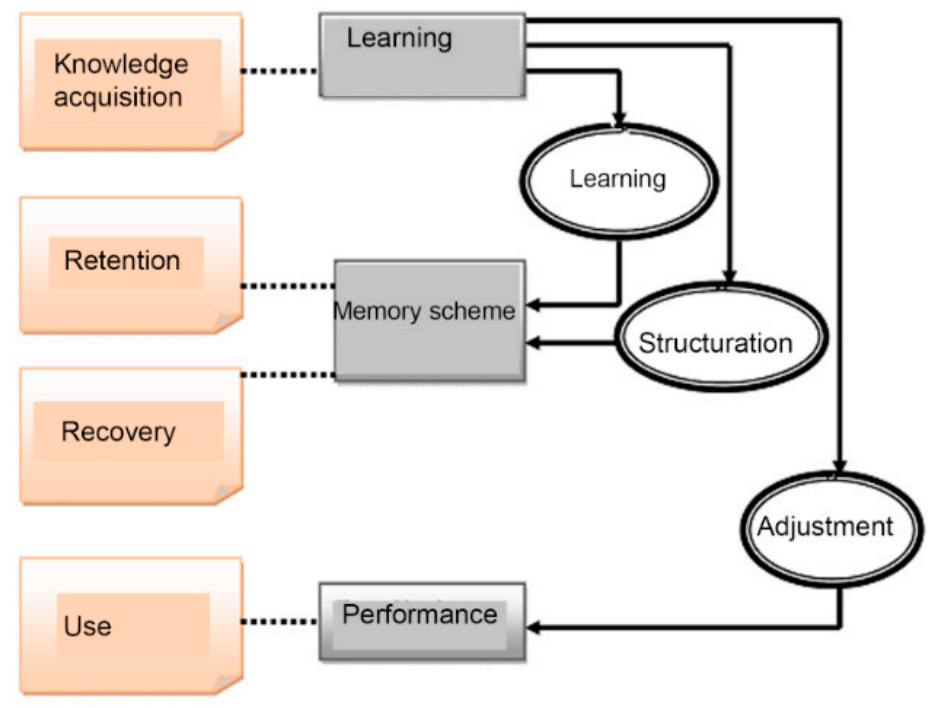

Figure 3. Knowledge understanding framework in the maintenance activity.

There are challenges that make difficult a proper functioning of the knowledge transfer such as the lack of availability to address the important actions and cultural barriers explained in Table 3. It is remarkable the massive use of informal mechanisms used to transfer the knowledge which creates "closed" knowledge making it difficult to share into members of the organization. According to the participants in this research, the efficient way to improve self-learning is through the possibility to apply their knowledge on different activities of the organization. This creates motivation in the staff along with knowledge on new tools and acquisition, use and transfer of internal and external knowledge.

Table 3. Tools, barriers and facilitators in KM in maintenance activity.

\begin{tabular}{|c|c|c|}
\hline $\begin{array}{c}\text { Studied Phenomenon } \\
\text { Category }\end{array}$ & Maintenance Operation Technicians & Maintenance Managers \\
\hline $\begin{array}{c}\text { Knowledge } \\
\text { Management Tools }\end{array}$ & $\begin{array}{l}\text { Information and knowledge maps. } \\
\text { Agile and simple systems to capture experiences. } \\
\text { Mobile computing tools to capture images, videos and experiences. }\end{array}$ & $\begin{array}{l}\text { Maintenance audits. } \\
\text { Energy audits. } \\
\text { Knowledge audits. } \\
\text { Knowledge and information mapsCriticality diagram. }\end{array}$ \\
\hline $\begin{array}{c}\text { Knowledge } \\
\text { Management Barriers }\end{array}$ & $\begin{array}{l}\text { Shortage of time to properly address important actions. } \\
\text { Cultural barriers. } \\
\text { Culture base on "own knowledge" not shared. } \\
\text { Staff involvement. } \\
\text { Greater use of informal knowledge mechanisms. }\end{array}$ & $\begin{array}{l}\text { Shortage of time to properly address important actions. } \\
\text { Cultural barriers. } \\
\text { Maintenance staff involvement. } \\
\text { Involvement of managerial team of the company. } \\
\text { Greater use of informal knowledge mechanisms. }\end{array}$ \\
\hline $\begin{array}{l}\text { Knowledge } \\
\text { Management } \\
\text { Facilitators }\end{array}$ & $\begin{array}{l}\text { Open and flexible proactive organizational culture. } \\
\text { Participatory management style. } \\
\text { Personal motivation of the employee. } \\
\text { Learning opportunity. } \\
\text { Organizational culture of maintenance area. } \\
\text { Management style. } \\
\text { media. } \\
\text { Use of knowledge manager related to maintenance activities. }\end{array}$ & $\begin{array}{l}\text { Open and flexible proactive organizational culture. } \\
\text { Participatory management style. } \\
\text { Personal motivation of the employee. } \\
\text { Learning opportunity. } \\
\text { Organizational culture of maintenance area. } \\
\text { Management style. } \\
\text { Physical space. } \\
\text { Management style. } \\
\text { Media. } \\
\text { Use of knowledge manager related to maintenance activities. }\end{array}$ \\
\hline Observations & $\begin{array}{l}\text { Handwritten personal notes which are not shared with the rest of } \\
\text { the team, which hamper the transmission and use of knowledge } \\
\text { between organization. }\end{array}$ & $\begin{array}{l}\text { It is important to have knowledge on general management } \\
\text { since it promotes the improvement in knowledge } \\
\text { management and maintenance optimization, with a } \\
\text { medium- and long-term vision. }\end{array}$ \\
\hline $\begin{array}{l}\text { Results of Proper } \\
\text { Management in } \\
\text { Maintenance Activity }\end{array}$ & \multicolumn{2}{|c|}{$\begin{array}{ll}\text { - } & \text { Capture of strategic tacit knowledge of maintenance technicians. } \\
\text { - } & \text { Resolutions of critical breakdowns in shortest time (especially the non-cyclical ones). } \\
\text { - } & \text { Reduction of operating maneuver time. } \\
\text { - } & \text { Facilitate sector change or staff substitutions. } \\
\text { - } & \text { Capture and transmission of information of subcontractor companies. } \\
\text { - } & \text { Share knowledge of employees that can be used by others to detect new improvement opportunities. } \\
- & \text { Improved knowledge of equipment and facilities reliability. } \\
- & \text { Improved knowledge for the detection and improvement of the efficiency actions. } \\
- & \text { time optimization }\end{array}$} \\
\hline
\end{tabular}


Table 3 shows the main categories that identify the different tools, facilitators and barriers in process of knowledge management.

\section{Conclusions}

This study is focused on components of a Kantian process where the ways in which the companies transfer, generate and use their knowledge are analyzed, along with the damages that can occur in the organization.

Proper knowledge management affects positively on different actions of a company, such as those mentioned in the Table 3 in results, where various activities can be done with a proper functioning of knowledge management. To create strategic value, it is important to combine internal and external knowledge.

A proactive and participatory style in knowledge management promotes new ideas and enhances the knowledge management itself along with self-learning, which is a key factor in activities where the demand for swift actions is higher.

It is also remarkable the existence of challengessuch as informal meetings for the generation and transfer of knowledge between technicians. Other challenges are the lack of use of the different audits and to spread the "know-how" system into the maintenance staff it must be simple and easy so it can be shared between them.

To conclude, there is a clear need for a knowledge manager as a key factor in transfer and use of knowledge. A knowledge manager is a person with high experience in operational maintenance areas and high technical training and, therefore, this figure can create efficiency in knowledge management so, the transfer of knowledge must be a priority in the maintenance industry, and it must be included in the strategic planning of the company.

Author Contributions: J.C.-C. developed the methodology; J.C.-C. and J.-A.C.-C. prepared the conceptualization and data curation; J.C.-C. and E.P.-L. gathered and analysed the data; J.C.-C. and J.-A.C.-C. wrote the paper. All authors have read and agreed to the published version of the manuscript.

Funding: This work has been conducted within the framework of the CONDAP project "Digital skills for workplace mentors in construction sector apprenticeships" funded by the European Commission within the Key Action 2: Cooperation for innovation and the exchange of good practices, reference number 2018-1-UK01-KA202-048122.

Acknowledgments: Sincere appreciation to the participation and dedication of the involved members in this research, mostly formed by maintenance engineering professionals as well as participant companies.

Conflicts of Interest: The authors declare no conflict of interest.

\section{References}

1. Isworowati, D.A.; Muhammad, F.; Kurniawati, A.; Kurniawan, M.T. Knowledge Management System for Maintenance Activity: Case Study at the Maintenance Department of XYZ Corporation. In Proceedings of the IEEE International Conference on Industrial Engineering and Engineering Management (IEEM), Macao, China, 15-18 December 2019; pp. 139-143.

2. Carcel-Carrasco, F.J.; Rodriguez-Mendez, M. Industrial maintenance and tacit knowledge: An introduction about its incidence. Dyna Manag. 2013, 1. [CrossRef]

3. Wilkesmann, M.; Wilkesmann, U. Industry4.0-organizing routines or innovations? Vine J. Inf. Knowl. Manag. Syst. 2018, 48, 238-254. [CrossRef]

4. Lu, Y. Industry4.0: A survey on technologies, applications and open research issues. J. Ind. Inf. Integr. 2017, 6, $1-10$.

5. Maier, R.; Hadrich, T. Knowledge management systems. In Encyclopedia of Knowledge Management, 2nd ed.; IGI Global: Hershey, PA, USA, 2011; pp. 779-790.

6. Sánchez, M.; Chaminade, C.; Escobar, C. En busca de una aproximación metodológica. Ekon. Rev. Vasca Econ. Í 1999, 45, 188-213.

7. OCDE. Medición de la Gestión de Conocimientos en las Empresas: Primeros Resultados; OCDE: Paris, France, 2004. 
8. Alsyouf, I. The role of maintenance in improving companies, productivity and profitability. Int. J. Prod. Econ. 2007, 105, 70-78. [CrossRef]

9. Lopez, P.; Centeno, G. Integrated system to maximize efficiency in transit maintenancedepartments. Int. J. Product. Perform. Manag. 2006, 55, 638-654. [CrossRef]

10. Razmi-Farooji, A.; Kropsu-Vehkaperä, H.; Härkönen, J.; Haapasalo, H. Advantages and potential challenges of data management in e-maintenance. J. Q. Maint. Eng. 2019, 25, 378-396. [CrossRef]

11. Mansor, M.A.; Ohsato, A.; Sulaiman, S. Knowledge management for maintenance activities in the manufacturing sector. Int. J. Automot. Mech. Eng. 2012, 5, 612-621. [CrossRef]

12. Garcia-Perez, A.; Cegarra-Navarro, J.G.; Bedford, D.; Thomas, M.; Wakabayashi, S. Knowledge Capabilities-Roles, Responsibilities, Placement. Critical Capabilities and Competencies for Knowledge Organizations; (Working Methods for Knowledge Management); Emerald Publishing Limited: Bingley, UK, 2019; pp. 95-114. [CrossRef]

13. Sols, A. Fiabilidad, Mantenibilidad, Efectividad, Unenfoque Sistémico; UnivPontificaComillas: Comillas, Madrid, 2000.

14. Pauleen, D. Personal knowledge management: Putting the "person" back into the knowledge equation. Online Inf. Rev. 2009, 33, 221-224. [CrossRef]

15. Volkel, M.; Haller, H. Conceptual data structures for personal knowledge management. Online Inf. Rev. 2009, 33, 298-315. [CrossRef]

16. Gunjal, B. Knowledge Management: Why Do We Need it for Corporates (April 21, 2019). Malays. J. Libr. Inf. Sci. 2019. [CrossRef]

17. Muñoz, J. Sobre gestión del conocimiento, un intangible clave en la globalización. Econ. ÍA Ind. 1999, 330, 61-70.

18. Cárcel Carrasco, F.J. La gestión del Conocimiento en la Ingeniería del Mantenimiento Industrial: Investigación Sobre la Incidencia en sus Actividades Estratégicas; OmniaScience: Barcelona, Spain, 2014. [CrossRef]

19. Polanyi, M. The Tacit Dimension; Routledge \& Kegan Paul: London, UK, 1966.

20. Spender, J.C. Organizational knowledge, learning and memory: Three concepts in search of a theory. J. Organ. Chang. Manag. 1996, 9, 63-78. [CrossRef]

21. Nonaka, I. The Knowledge-Creating Company. Harv. Bus. Rev. 1991, 85, 162.

22. Nonaka, I.; Konno, N. “The concept of "Ba": building a foundation for knowledge creation. Calif. Manag. Rev. 1998, 40, 40-54. [CrossRef]

23. De Andrade, F.G.; Araújo, C.K.C.; Basso, S.; Przybysz, A.L.; Francisco, A.C. The Perception of Knowledge Management by Small and Medium-Sized IT Companies, Campos Gerais, Brazil. In International Joint Conference on Industrial Engineering and Operations Management; Springer: Cham, Switzerland, 2019; pp. 522-531.

24. Orenga-Roglá, S.; Chalmeta, R. Methodology for the implementation of knowledge management systems 2.0. Bus. Inf. Syst. Eng. 2019, 61, 195-213. [CrossRef]

25. Ngoc-Tan, N.; Gregar, A. Knowledge Management and Its Impacts on Organisational Performance: An Empirical Research in Public Higher Education Institutions of Vietnam. J. Inf. Knowl. Manag. 2019, 18, 1950015. [CrossRef]

26. Martins, V.W.B.; Rampasso, I.S.; Anholon, R.; Quelhas, O.L.G.; LealFilho, W. Knowledge management in the context of sustainability: Literature review and opportunities for future research. J. Clean. Prod. 2019, 229, 489-500. [CrossRef]

27. Nisar, T.M.; Prabhakar, G.; Strakova, L. Social media information benefits, knowledge management and smart organizations. J. Bus. Res. 2019, 94, 264-272. [CrossRef]

28. Colace, F.; DeSanto, M.; Pascale, F.; Lemma, S.; Lombardi, M. BotWheels: A Petri Net based Chatbot for Recommending Tires. DATA 2017,350-358. [CrossRef]

29. Maxwell, J.A. Qualitative Research Design: An Interactive Approach; Sage Publications: Thousand Oaks, CA, USA, 1996.

30. Eisenhardt, K. Building theories from case studies research. Acad. Manag. Rev. 1989, 14, 532-550. [CrossRef]

31. Yin, R.K. Case Study Research: Designand Methods; Sage Publications: Thousand Oaks, CA, USA, 1995.

32. Rodríguez, G.; Gil, F.J.; García, J.E. Metodología de la Investigación Cualitativa; Ediciones Aljibe: Málaga, Spain, 1996. 
33. Hansen, M.T.; Nohria, N.; Tierney, T. What's your strategy for managing knowledge? Harv. Bus. Rev. 1999, 77, 106-116.

34. Nonaka, I.; Takeuchi, H. The Knowledge-Creating Company: How Japanese Companies Create the Dynamics of Innovation; Oxford University Press: New York, NY, USA, 1995.

35. Zapata, L. La Gestión del Conocimiento en Pequeñas Empresas de Tecnología de la Información: Una Investigación Exploratoria; Document de treball núm; Universitat Autònoma de Barcelona; Facultat de Ciències Econòmiques i Empresarials: Barcelona, Spain, 2001.

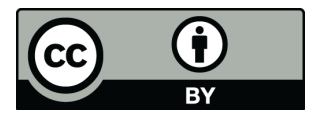

(C) 2020 by the authors. Licensee MDPI, Basel, Switzerland. This article is an open access article distributed under the terms and conditions of the Creative Commons Attribution (CC BY) license (http://creativecommons.org/licenses/by/4.0/). 